\title{
Polycyclic aromatic hydrocarbons (PAHs) in the atmospheres of two French alpine valleys: sources and temporal patterns
}

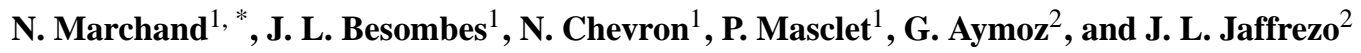 \\ ${ }^{1}$ LCME, ESIGEC, Université de Savoie, 73376 le Bourget du Lac, France \\ ${ }^{2}$ LGGE, CNRS, Université Joseph Fourier, 24 rue Molière, 38402 St Martin d'Hères, France \\ *Now at: LaMP, CNRS, Université Blaise Pascal, 14 avenue des Landais, 63177 Aubière, France
}

Received: 5 December 2003 - Published in Atmos. Chem. Phys. Discuss.: 2 February 2004

Revised: 29 June 2004 - Accepted: 12 July 2004 - Published: 2 August 2004

\begin{abstract}
Alpine valleys represent some of the most important crossroads for international heavy-duty traffic in Europe, but the full impact of this traffic on air quality is not known due to a lack of data concerning these complex systems. As part of the program "Pollution des Vallées Alpines" (POVA), we performed two sampling surveys of polycyclic aromatic hydrocarbons (PAHs) in two sensitive valleys: the Chamonix and Maurienne Valleys, between France and Italy. Sampling campaigns were performed during the summer of 2000 and the winter of 2001, with both periods taking place during the closure of the "Tunnel du Mont-Blanc". The first objective of this paper is to describe the relations between PAH concentrations, external parameters (sampling site localization, meteorological parameters, sources), and aerosol characteristics, including its carbonaceous fraction (OC and EC). The second objective is to study the capacity of PAH profiles to accurately distinguish the different emission sources. Temporal evolution of the relative concentration of an individual PAH (CHR) and the PAH groups BghiP+COR and $\mathrm{BbF}+\mathrm{BkF}$ is studied in order to differentiate wood combustion, gasoline, and diesel emissions, respectively. The results show that the total particulate PAH concentrations were higher in the Chamonix valley during both seasons, despite the cessation of international traffic. Seasonal cycles, with higher concentrations in winter, are also stronger in this valley. During winter, particulate PAH concentration can reach very high levels (up to $155 \mathrm{ng} . \mathrm{m}^{-3}$ ) in this valley during cold anticyclonic periods. The examination of sources shows the impact during summer of heavy-duty traffic in the Maurienne valley and of gasoline vehicles in the Chamonix valley. During winter, Chamonix is characterized by the strong influence of wood combustion in residential fireplaces, even if
\end{abstract}

Correspondence to: N. Marchand

(n.marchand@opgc.univ-bpclermont.fr) the temporal evolution of specific PAH ratios are difficult to interpret. Information on sources given by PAH profiles can only be considered in qualitative terms.

\section{Introduction}

Alpine valleys are unique transportation pathways in Europe, with a small number of corridors supporting the large traffic of heavy-duty trucks. This traffic, in addition to local emissions, can induce high levels of pollutants in these deep valleys when subjected to specific atmospheric dynamics in mountainous areas (Prévôt et al., 2000). The results presented here were obtained during the program "Pollution des Vallées Alpines" (POVA). This program focuses on atmospheric chemistry in two transit corridors between France and Italy: the Chamonix and Maurienne valleys (Fig. 1). This study benefits from an exceptional context: the closure of the "Tunnel du Mont Blanc" in the Chamonix valley for nearly 3 years after a large accident in March 1999. Consequently, most heavy-duty traffic in the area was taking place through the "Tunnel du Fréjus", in the Maurienne valley. This traffic was as large as that expected for 2010 (in 2001, an average of 7428 vehicles per day, including 4244 trucks). The general objectives of the POVA program are the comparative studies of atmospheric pollution and the modeling of atmospheric emissions and transport in these two French alpine valleys before and after the reopening of the "Tunnel du Mont Blanc" to heavy-duty traffic. The program includes several field campaigns, associated with 3D modeling (Brulfert et al., submitted, 2004 ${ }^{1}$ ). In this context, our

\footnotetext{
${ }^{1}$ Brulfert, G., Chemel, C., Chaxel, E., and Chollet, J. P.: Modelling photochemistry in alpine valleys, Atmos. Chem. Phys., submitted, 2004.
} 
specific objectives are to obtain a better knowledge of the particulate pollution and to estimate the respective influences of the main aerosol sources.

Investigations on the carbonaceous fraction of aerosols can yield information on their nature and sources. This fraction is composed of many compounds which constitute the organic carbon (OC) and elemental carbon (EC) components (Penner and Novakov, 1996). Within the organic carbon component, the Polycyclic Aromatic Hydrocarbons (PAHs) are prevalent constituents of atmospheric pollution. Due to their low natural emission (Dachs et al., 1996; Nikolaou et al., 1984), PAHs are good tracers of anthropogenic sources of input to the atmosphere. They are mainly formed during incomplete combustion or pyrolysis of organic materials, including oil derivatives, coals, natural gas, biomass and household wastes (Besombes et al., 2001). In addition, because of their potential carcinogenic effects (IARC 1983, 1987), PAHs are now regarded as priority pollutants by both the United States Environmental Protection Agency and the European Environment Agency.

In urban and near-city environments, the main PAH sources are vehicular emissions and domestic heating ( $\mathrm{Si}$ moneit, 2002; Nikolaou et al., 1984; Rogge et al., 1996; $\mathrm{Li}$ and Kamens, 1993), with the contribution of the latter increasing significantly during winter (Schauer and Cass, 2000; Carrichia et al., 1999; Pistikopoulos et al., 1990a; Nielsen, 1996). Studies of PAH chemical signatures have been performed for more than 30 years. Due to the large changes in emission ratios and chemical profiles between each of these sources, PAHs have tentatively been used for their discriminative and apportionment capability in air quality studies (Khalili et al., 1995; Li and Kamens, 1993; Pistikopoulos et al., 1990a; Nielsen, 1996; Aceves and Grimalt, 1993; Harrison et al., 1996, Kavouras et al., 2001). However, great variability is observed in the emission ratios of PAHs (see Sect. 3). Therefore, it is generally difficult to quantify the impact of several sources based only on PAHs. Our study takes place in a simpler context, with fewer source types than those found in the urban environment. It is therefore interesting to evaluate our ability to resolve these sources in the valleys with PAH profiles.

As part of the POVA program, two intensive field campaigns were performed in the summer of 2000 and the winter of 2001. After summarizing our current knowledge of PAH emissions from anthropogenic sources, we discuss our results in terms of comparisons of concentrations and PAH profiles between seasons and valleys. The first objective of our study is to describe the relations between PAH concentrations, external parameters (sampling site localization, meteorological parameters, sources), and aerosol characteristics, including its carbonaceous fraction (OC and EC). The second objective is to study the capacity of PAH profiles to accurately discriminate sources.

\section{Experimental section}

\subsection{Sampling campaigns and sampling sites}

Figure 1 presents the morphology of the two valleys investigated. The Chamonix valley, about $17 \mathrm{~km}$ in length, is surrounded by mountains reaching between 3000 and $4800 \mathrm{~m}$ above sea level (m a.s.1.). It is characterized by some of the steepest slopes in the Alps. The valley floor, oriented SW$\mathrm{NE}$ and at about $1000 \mathrm{~m}$ a.s.l., is very narrow and seldom exceeds a width of $1.5 \mathrm{~km}$. The Maurienne valley is much longer (roughly $130 \mathrm{~km}$ ) and wider (up to several $\mathrm{km}$ at some places). The narrowest part (less than $1 \mathrm{~km}$ ) is located in the Orelle pass (M2). The surrounding peaks vary between 2500 and $3800 \mathrm{~m}$ a.s.l., and the valley floor increases from $555 \mathrm{~m}$ a.s.l. (in Saint Jean de Maurienne, M5) to $1373 \mathrm{~m}$ a.s.l. (in Sollières, M3). The lower section of the valley, from the beginning of the valley to Orelle, has an approximate NWSE orientation. A second section, from Orelle (M2) to the upper part of the valley, possesses an approximate SW-NE orientation.

The two valleys are among the most important European north-south routes across the Alps. Each valley allows a direct connection between France and Italy via highways in their respective tunnels. Since the closure of "Tunnel du Mont-Blanc", the traffic in the Chamonix valley is essentially linked to local and tourism activities, with most of the traffic represented by personal vehicles (on average, only $2 \%$ of the traffic consists of tourism buses and light-duty trucks for local delivery).The average traffic density was about 13300 vehicles per day (veh. $\mathrm{d}^{-1}$ ) during the period June 2000-April 2002, with a maximum of about 30000 veh.d ${ }^{-1}$ during August on National Road 205 (N205). The weekly traffic also showed a slight maximum on Saturday, corresponding to elevated tourist activity. It should be noted that $50.1 \%$ of personal vehicles are using diesel fuel in France (estimate derived for the year 2000).

In the Maurienne valley, the traffic is distributed on a main road (N6) and the highway (A43). The personal vehicle traffic was of the order of 6000 veh. $\mathrm{d}^{-1}$ during our study, with a small maximum on weekends. The heavyduty traffic essentially takes place on the highway, with an average of about 3000 trucks. $^{-1}$. It reaches a maximum on Wednesdays (6000 trucks. $\left.\mathrm{d}^{-1}\right)$, with a minimum on Sundays $\left(<1000\right.$ trucks. $\left.\mathrm{d}^{-1}\right)$. Industrial activities are only taking place in the Maurienne valley, with some chemical and metallurgic plants located near the main towns in the valley (Saint Jean (site M5) and Saint Michel de Maurienne).

In alpine valleys, wood-burning sources are potentially important. On a regional scale (Région Rhônes-Alpes), wood burning represents $20 \%$ of the total energy used for individual heating (value derived for the year 1996). The contribution of wood burning can be considered more important in the valleys because of specific climactic conditions, traditions, and tourist activities. Nevertheless, no precise 

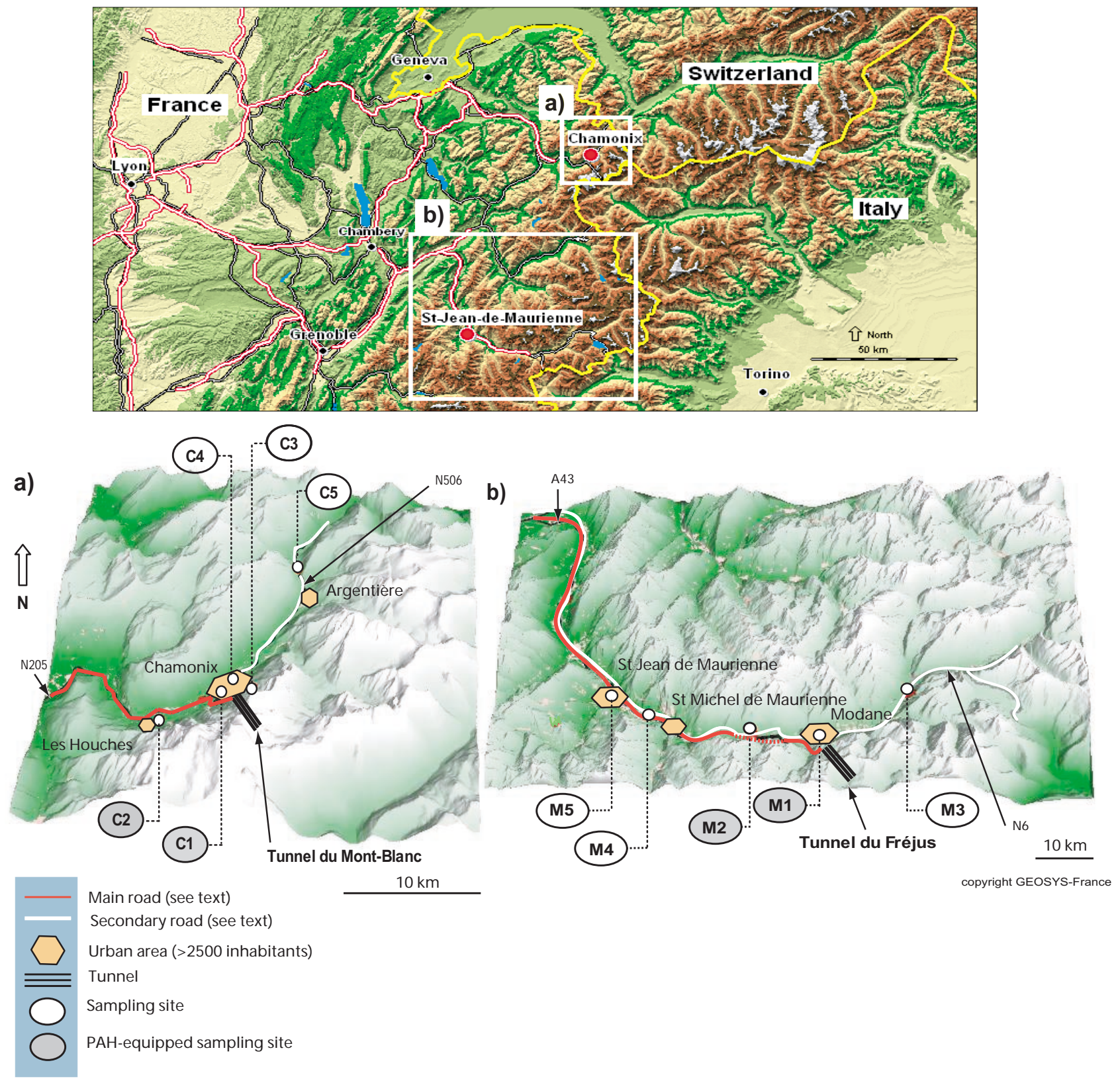

Fig. 1. Map of the two alpine valleys, (a) Chamonix Valley and (b) Maurienne Valley, and sampling sites during the summer 2000 and winter 2001 campaigns, respectively. Shaded points (C1, C2 and M1, M2) represent sites instrumented for PAH sampling.

estimations were performed in the two valleys during the program.

As part of the POVA program, two 15-day campaigns were performed while the international traffic was stopped in the Chamonix valley. A summer campaign took place in 2000, during 14-21 August in the Chamonix valley and 22-29 August in the Maurienne valley. A winter campaign took place in 2001, during 16-22 January in the Chamonix valley and 25-31 January in the Maurienne valley. In each valley, five sampling sites were instrumented with various aerosol or gas samplers, including automatic analyzers for NOx, ozone, and $\mathrm{PM}_{10}$, and aerosol collection for chemical analysis. Not all measurements were performed at every site. The locations of these sites ( $\mathrm{C} 1$ to $\mathrm{C} 5$ and M1 to M5 in the valleys of Chamonix and Maurienne, respectively) are presented on Fig. 1. PAHs were collected at two sites in each valley during winter: Le Clos de l'Ours (C1) and Les Houches (C2) in the Chamonix valley, and Modane (M1) and Orelle (M2) in the Maurienne valley. PAHs were only collected at one site in each valley during the summer: Le Clos de l'Ours (C1) and 
Modane (M1). Sampling sites can be described using criteria proposed by the European Environmental Agency (Larssen et al., 1999). According to these criteria, we can classify $\mathrm{C} 1$ and M1 as Urban Background sites ( $<2500$ vehicles/day within $50 \mathrm{~m}$ ), and $\mathrm{C} 2$ and $\mathrm{M} 2$ as Near City Background sites (distance from large pollution sources: $3-10 \mathrm{~km}$ ).

\subsection{Sample collection and analysis}

The sampling and analytical procedures for the determination of PAH atmospheric concentrations are described in detail by Besombes et al. (2001). Briefly, airborne particulates were collected by high-volume samplers $\left(50 \mathrm{~m}^{3} \cdot \mathrm{h}^{-1}\right.$ on average) on pre-cleaned glass fiber filters (GF/F Whatmann filter, $210 \times 270 \mathrm{~mm}$ ). Sampling duration at all sites was $24 \mathrm{~h}$ (starting at 08:00 h local) during the summer campaign, and 12:00 h (starting at 08:00 $\mathrm{h}$ and 20:00 h local, respectively) during the winter campaign. After collection, filters were stored at a low temperature $\left(-4^{\circ} \mathrm{C}\right)$ in aluminum sheets sealed in polyethylene bags, until analysis.

Samples were subjected to soxhlet extraction for $3 \mathrm{~h}$ (BUCHI B-811) with a mixture of dichloromethane and cyclohexane $(2 / 1 \mathrm{v} / \mathrm{v})$. PAH analyses were performed by reversed-phase high-performance liquid chromatography on a Vydac C18 column (length $25 \mathrm{~cm}$, granulometry $5 \mu \mathrm{m}$, and internal diameter $4.5 \mathrm{~mm}$ ) with a ternary elution gradient (methanol, water acetonitrile). All solvents were degassed using helium sparging to eliminate possible oxygen quenching during fluorescence. PAHs were identified and quantified by UV fluorescence at variable excitation and emission wavelengths. With this method, the following 11 PAHs were determined quantitatively: fluoranthene (FLA), pyrene (PYR), chrysene (CHR), benzo[a]anthracene (BaA), benzo(e)pyrene $(\mathrm{BeP})$, benzo[b]fluoranthene $(\mathrm{BbF})$, benzo[k]fluoranthene (BkF), benzo[a]pyrene (BaP), benzo[ghi]perylene (BghiP), indeno(1,2,3-cd)pyrene (IP), and coronene (COR). Overall analytical and sampling errors were estimated between 18 and $41 \%$, depending on the PAH considered (Marchand, 2003).

Measurements for NOx (Thermo Environmental Instruments 42C) and $\mathrm{PM}_{10}$ (TEOM1400A, R and P) were conducted on a $15 \mathrm{~min}$ basis at the same sites. Parallel sampling for EC and OC analysis were conducted with open-face filters on a 4 or 6-h basis, according to the site and the season. We used QMA quartz filters $(47 \mathrm{~mm})$ pre-fired for $1 \mathrm{~h}$ at $800^{\circ} \mathrm{C}$ in order to lower the blank levels. Filters were kept and transported by packs of 20 in leak-proof glass jars before sampling. After sampling, they were stored at $-18^{\circ} \mathrm{C}$ in individual Petri slides wrapped in aluminum foil in sealed bags, until analysis. Analyses for OC and EC took place at INW, Gent, Belgium, using a thermo-optical method on a Sunset Lab analyzer (Birch and Carry, 1996). The temperature ramp uses four steps up to $870^{\circ} \mathrm{C}$ under pure helium for the quantification of $\mathrm{OC}$, and four steps up to $900^{\circ} \mathrm{C}$ with a mixture of $98 \% \mathrm{He}+2 \% \mathrm{O}_{2}$ for that of EC. Arithmetic means were used to calculate 12 or $24 \mathrm{~h}$ average concentrations for the same time steps as the PAH samplings.

\section{A short review of studies on particulate PAH emis- sions}

There is a large amount of literature dealing with emissions of PAH by various anthropogenic combustion sources. As mentioned previously, residential heating with wood fires, as well as vehicular emissions, are considered the main sources of PAHs in urban and near-city environments. Table 1 summarizes some of the emission rates of total particulate PAH presented in published studies. Calculations of total particulate PAH emission rates have been made of the basis of the following 11 PAHs: FLA, PYR, BaA, CHR, BeP, BbF, BkF, BaP, BghiP, IP and COR.

Wood combustion, as a domestic heating source, plays a significant role in contributing to organic carbon (OC) emissions. Schauer et al. (1996) and Schauer and Cass (2000) calculated that an urban environment in Los Angeles experienced an annual average contribution by wood combustion to ambient OC in a range between 5 and 22\% (year 1982), with maxima between 30 and $65 \%$ during winter months (results for the year 1996). With a PAH/OC ratio higher in emissions resulting from wood combustion than those from vehicular emissions (Table 1), wood combustion in residential areas can represent one of the most significant PAH sources ( $\mathrm{Li}$ and Kamens, 1993). This is corroborated by very high PAH emission rates (ranging between 4 and $14 \mathrm{mg} \mathrm{kg}^{-1}$ of burned wood), being 1 to 3 orders of magnitude larger than those calculated from vehicular emissions (Table 1). The latter emission rates are estimated between 0.01 and $0.07 \mathrm{mg} \mathrm{kg}^{-1}$ for recent gasoline-powered light vehicles, and between 0.25 and $1.4 \mathrm{mg} \mathrm{kg}^{-1}$ for heavy-duty trucks.

The large standard deviations with these values make it very difficult to obtain precise estimates of emission rates, due mainly to the large number of parameters influencing such estimates. In the case of vehicular emissions, the most important parameter influencing the variability of emission rates is the engine temperature. Indeed, Combet et al. (1993) highlighted a PAH emission that was 20 times larger during a cold start than during warm use, for gasoline-powered light vehicles (average of 10 vehicles on a slow urban cycle). This difference between cold start and warm use also exists for diesel vehicles, but to a lesser extent (with a factor of 1.5 only, for an average of 20 vehicles). Fabrication year, as well as mean velocity, also has a significant influence on PAH emission rates (Combet et al., 1993). The use of a catalytic converter decreases the quantities of emitted PAH by a factor ranging between 20 and 1000 (Schauer et al., 2002; Rogge et al., 1993; Paturel et al., 1996). Finally, the composition of the fuel, especially its concentration of $\mathrm{PAH}$, also influences the quantities emitted into the atmosphere (Marr 
Table 1. Emission rates of PAH $\left[\mu \mathrm{g} . \mathrm{kg}^{-1}\right]$ for different sources.

\begin{tabular}{|c|c|c|c|c|}
\hline $\operatorname{PAH}(\Sigma)^{\mathrm{a}}$ & $\begin{array}{c}\text { Emission rate } \\
\left(\mu \mathrm{g} \cdot \mathrm{kg}^{-1}\right)\end{array}$ & $\begin{array}{l}\Sigma / \mathrm{OC} \\
(\%)\end{array}$ & Observations & Reference \\
\hline \multicolumn{5}{|l|}{ Vehicular sources } \\
\hline \multicolumn{5}{|l|}{ Gasoline } \\
\hline Catalysed-equipped light vehicles & $8.1^{\ddagger}(0.7)^{\mathrm{b}}$ & 0.02 & Average of 9 vehicles $(1986-1994)^{\mathrm{d}, \mathrm{e}}$ & Schauer et al. (2002) \\
\hline Catalysed-equipped light vehicles & $350(26)^{\mathrm{c}}$ & 2.8 & Average of 7 vehicles $(1977-1983)^{\mathrm{d}, \mathrm{e}}$ & Rogge et al. (1993) \\
\hline Light vehicles & $72.5^{\dagger}$ & - & Calculated from tunnel measurements (San Francisco) & Miguel et al. (1998) \\
\hline \multicolumn{5}{|l|}{ Diesel } \\
\hline Heavy-duty trucks & $240(60.2)^{b}$ & 0.5 & Average of 2 heavy-duty trucks $(1987)^{\mathrm{d}, \mathrm{e}}$ & Rogge et al. (1993) \\
\hline Heavy-duty trucks & $1403^{\dagger}$ & - & Calculated from tunnel measurements (San Francisco) & Miguel et al. (1998) \\
\hline \multicolumn{5}{|c|}{ Wood combustion in residential fireplaces } \\
\hline & $13700^{\ddagger}$ & 2.5 & Pine & Schauer et al. (2001) \\
\hline & $6900^{\ddagger}$ & - & Pine & Rogge et al. (1998) \\
\hline & $5000^{\ddagger}$ & 1.7 & Oak & Schauer et al. (2001) \\
\hline & $4900^{\ddagger}$ & - & Oak & Rogge et al. (1998) \\
\hline & $3700^{\ddagger}$ & 1 & Eucalyptus & Schauer et al. (2001) \\
\hline Coal & $950.10^{3}$ & 82 & Average of 4 coal ranks & Oros and Simoneit (2000) \\
\hline \multicolumn{5}{|c|}{ 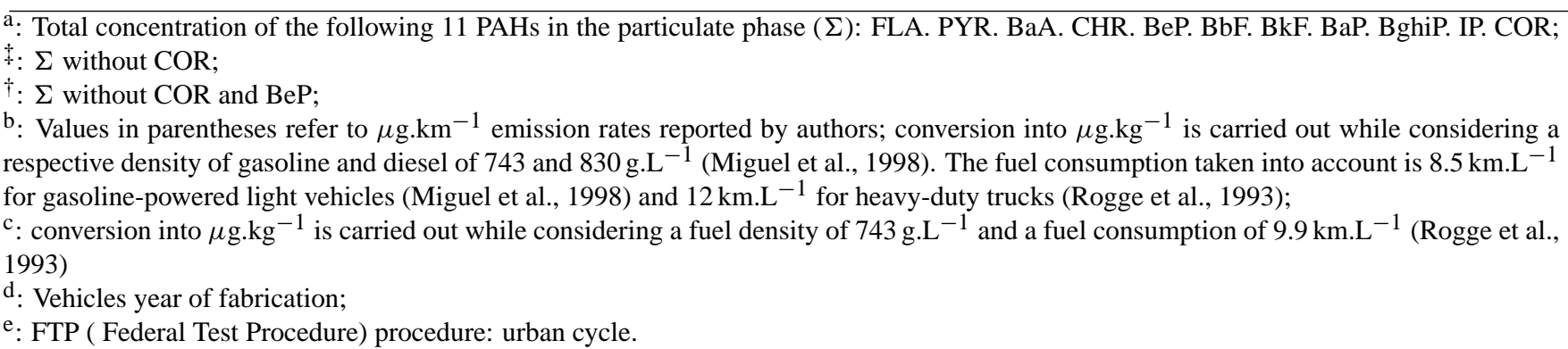 } \\
\hline
\end{tabular}

et al., 1999; Mi et al., 1998; Rogge et al., 1993). Marr et al. (1999) highlighted a strong correlation between chemical composition and PAH emission rates for gasoline-powered light vehicles, underlining the importance of unburned fuel as a significant PAH source. For diesel vehicles, the composition of the engine oil seems to be the important factor influencing PAH emissions (Schauer et al., 2002).

In the case of residential heating, combustion conditions (temperature, moisture, availability of oxygen) largely influence emission rates, as does the nature of the fuel (wood type, presence of foliage)(Standley and Simoneit, 1987; Jenkins et al., 1996). Jenkins et al. (1996) report that smoldering combustions emit 4-5 times more PAHs that flaming combustions.

With the entire range of PAHs being emitted more or less by each type of source, many studies over the last 30 years focused on the determination of PAH chemical profiles as fingerprints of such sources ( $\mathrm{Li}$ and Kamens, 1993). These studies resulted in many observations in which emission ratios were considered source-specific.

First of all, gasoline vehicular emissions are characterized by PAHs with higher molecular weight than those measured in diesel exhaust. This is particularly the case for BghiP and COR (Rogge et al., 1993; Miguel et al., 1998; Miguel and Pereira, 1989), and seems to be correlated with engine operating temperatures (Rogge et al., 1993; Combet et al., 1993; Schauer et al., 2002). Combet et al. (1993) showed that BghiP emission rates were approximately 55\% higher during warm driving cycles than during cold driving cycles. The same result is obtained for IP, but to a lesser extent (increase of $25 \%$ only). These results are also in line with the study of Marr et al. (1999), which showed a direct correlation between fuel and exhaust compositions for gasoline vehicles. In this study, only BghiP showed emission rates that were clearly higher than those extrapolated from the fuel composition. This result suggests pyrosynthetic formation processes within the engine, processes that require high temperatures (Marr et al., 1999; Combet et al., 1993). Thus, gasoline emissions can be characterized by an abundance of BghiP and COR (Nielsen, 1996; Li and Kamens, 1993; Rogge et al., 1993).

Marr et al. (1999) did not demonstrate any correlation between fuel and exhaust compositions for diesel vehicles. This suggests the importance of unburned lubricating oil 

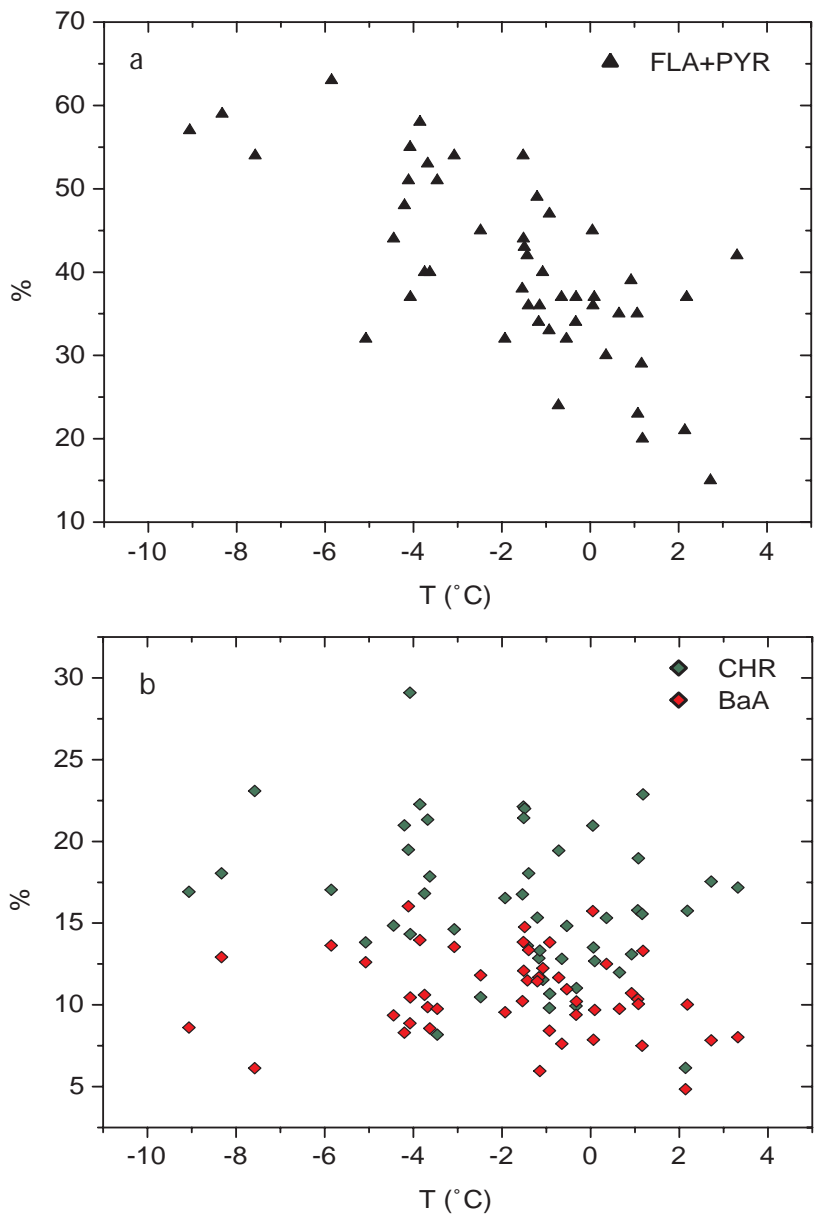

Fig. 2. PAH relative concentration versus temperature for the winter data set. (a) calculated on the basis of $\Sigma$; (b) calculated on the basis of $\Sigma^{\prime}$.

emissions and internal formation processes. Taking into account the relative abundances of heavy PAHs, being significantly smaller for diesel vehicles than for gasoline vehicles, engine oil rejections seem to be an important factor in influencing the composition of diesel exhausts. This same process is also suggested for hopane emissions (Schauer et al., 2002). Finally, Combet et al. (1993) did not observe any modification of the PAH chemical signature according to engine temperatures. Diesel emissions are usually distinguished from gasoline emissions by greater relative concentrations of $\mathrm{BbF}$, BkF and CHR (Li and Kamens, 1993; Hering et al., 1984; Li et al., 1996; Duran et al., 2001; Rogge et al., 1993).

PAH chemical signatures of wood combustion aerosols also show an important proportion of $\mathrm{CHR}$, as well as $\mathrm{BbF}$ and $\mathrm{BkF}$, but to a lesser extent than in diesel emissions. In the study of Rogge et al. (1998), CHR represents $70 \%$ by mass of a selection of 9 particulate PAHs emitted during oak combustion, with a high emission rate of $2.8 \mathrm{mg} \cdot \mathrm{kg}^{-1}$. However, for the same wood and in equivalent conditions (residential fireplace), the data reported by Schauer et al. (2001) on the basis of the same 9 PAHs reveals a significantly lower CHR contribution ( $30 \%$; emission rate: $0.75 \mathrm{mg} \cdot \mathrm{kg}^{-1}$ ). As in the case of diesel emissions, high molecular weight PAHs (BghiP, IP and COR) show a weak contribution to total PAH emissions. They are not emitted at all during hard wood combustion (Oros and Simoneit, 2001b; Schauer et al., 2001), but are more abundant during soft wood combustion (Oros and Simoneit, 2001a; Schauer et al., 2001). However, they were measured (particularly COR) during bush (Freeman and Catell, 1990) and savanna fires (Masclet et al., 1995). Separating profiles resulting from diesel and wood combustion emissions is thus relatively difficult on the basis of PAH only. It seems necessary to consider correlations with other tracers in cases involving multiple sources, and not only with the relative $\mathrm{PAH}$ contribution, in order to obtain an accurate estimation of the impact of these anthropogenic sources.

\section{Results and discussion}

\subsection{Average total concentrations and seasonal variations}

The total PAH concentration (called $\Sigma$ ) represents the sum of the individual concentrations of the 11 PAHs quantified in this study. Among these, PAH, FLA, PYR, BaA and CHR are the most volatile, being present in the atmosphere in both a particulate and gas phase (at $\mathrm{T}=20^{\circ} \mathrm{C}$ $\mathrm{C}_{\text {particles }} / \mathrm{C}_{\text {gas }}=0.0036,0.056,0.18,1.3$ for FLA, PYR, BaA and CHR, respectively, assuming a total aerosol mass of $100 \mu \mathrm{g} \mathrm{m}^{-3}$ (Seinfeld and Pandis, 1998)). In order to estimate the influence of Gas/Particle partitioning on total PAH concentrations, it is useful to study the relative concentrations of these semi-volatile PAHs as a function of temperature. As shown in Fig. 2, FLA and PYR are the only PAHs showing a significant trend between their relative concentrations and ambient temperature during the winter POVA campaign. It should be noted that the relative concentrations of $\mathrm{BaA}$ and $\mathrm{CHR}$ are calculated in relation to $\Sigma^{\prime}\left(\Sigma^{\prime}=\Sigma\right.$-FLAPYR) to avoid biases due to the correlation between FLA and PYR and temperature. The same observations can be made for the results obtained during the summer campaign. However, due to the impact of source and photo-oxidation processes, no global trend can be found between relative concentration (even with FLA and PYR) and temperature when evaluating both the winter and summer data sets. Considering these results, Gas/Particle partitioning and physical artefacts do not appear to act as fundamental factors governing the relative concentrations of $\mathrm{CHR}, \mathrm{BaA}$ and heavier PAHs. Thus, in the following discussions, the relative concentrations of PAHs are calculated on the basis of $\Sigma^{\prime}$.

Table 2 presents all the results, for the 2 campaigns and every site, of the average concentrations of individual $\mathrm{PAH}, \Sigma, \Sigma^{\prime}, \mathrm{PM}_{10}, \mathrm{EC}$, and OC, together with the average temperature. The general levels of PAH concentrations (0.7-1.3 ng. $\mathrm{m}^{-3}$ during summer and 3.5-47.6 ng. $\mathrm{m}^{-3}$ during 
Table 2. Average results on individual PAH, $\Sigma, \Sigma^{\prime}$, EC, OC, PM10, T and PAH relative concentrations for the summer and winter campaigns in the two valleys.

\begin{tabular}{|c|c|c|c|c|c|c|c|c|c|c|c|c|}
\hline \multirow[b]{3}{*}{$\mathrm{T}^{\circ} \mathrm{C}^{\mathrm{b}}$} & \multicolumn{4}{|c|}{ Summer } & \multicolumn{8}{|c|}{ Winter } \\
\hline & \multicolumn{2}{|r|}{$\mathrm{M}^{\mathrm{a}}$} & \multicolumn{2}{|r|}{$\mathrm{C} 1$} & \multicolumn{2}{|r|}{ M1 } & \multicolumn{2}{|r|}{$\mathrm{C} 1$} & \multicolumn{2}{|r|}{ M2 } & \multicolumn{2}{|r|}{$\mathrm{C} 2$} \\
\hline & 15.3 & (3.1) & 18.0 & (1.4) & -1.0 & (2.3) & -2.5 & (2.8) & -0.7 & (2.6) & -3.3 & (2.7) \\
\hline FLA (ng.m $\left.{ }^{-3}\right)$ & 0.21 & $(0.04), n=7^{c}$ & 0.35 & $(0.08), n=6$ & 1.76 & $(0.89), n=11$ & 13.91 & $(14.77), n=14$ & 0.66 & $(0.50), n=12$ & 5.75 & $(6.23), n=13$ \\
\hline PYR (ng.m ${ }^{-3}$ ) & 0.15 & $(0.05)$ & 0.29 & $(0.08)$ & 1.52 & $(0.80)$ & 10.84 & (11.66) & 0.57 & $(0.46)$ & 3.38 & $(4,98)$ \\
\hline $\mathrm{BaA}\left(\mathrm{ng} \cdot \mathrm{m}^{-3}\right)$ & 0.02 & $(0.01)$ & 0.05 & $(0.01)$ & 0.71 & $(0.32)$ & 2.71 & $(2.45)$ & 0.22 & $(0.15)$ & 1.00 & $(0,81)$ \\
\hline $\mathrm{CHR}\left(\mathrm{ng} \mathrm{m}^{-3}\right)$ & 0.06 & $(0.01)$ & 0.09 & $(0.02)$ & 0.87 & $(0.35)$ & 3.64 & $(3.71)$ & 0.36 & $(0.20)$ & 2.06 & $(2,58)$ \\
\hline $\mathrm{BeP}\left(\right.$ ng. $\left.\mathrm{m}^{-3}\right)$ & 0.05 & $(0.02)$ & 0.08 & $(0.02)$ & 1.06 & $(0.63)$ & 3.50 & (2.39) & 0.31 & $(0.16)$ & 1.83 & $(1,78)$ \\
\hline $\mathrm{BbF}\left(\right.$ ng. $\left.^{-3}\right)$ & 0.05 & $(0.02)$ & 0.09 & $(0.03)$ & 1.05 & $(0.39)$ & 2.95 & $(2.15)$ & 0.38 & $(0.23)$ & 1.53 & $(1,51)$ \\
\hline $\mathrm{BkF}\left(\mathrm{ng} \cdot \mathrm{m}^{-3}\right)$ & 0.02 & $(0.01)$ & 0.06 & $(0.03)$ & 0.45 & $(0.18)$ & 1.21 & $(0.95)$ & 0.17 & $(0.09)$ & 0.60 & $(0,60)$ \\
\hline $\mathrm{BaP}\left(\right.$ ng. $\left.\mathrm{m}^{-3}\right)$ & 0.02 & $(0.01)$ & 0.04 & $(0.01)$ & 0.71 & $(0.28)$ & 2.22 & $(1.35)$ & 0.23 & $(0.14)$ & 0.73 & $(0,61)$ \\
\hline $\operatorname{BgP}\left(\right.$ ng. $\left.^{-3}\right)$ & 0.03 & $(0.02)$ & 0.14 & $(0.07)$ & 0.67 & $(0.35)$ & 3.03 & (1.59) & 0.24 & $(0.13)$ & 0.73 & $(0,66)$ \\
\hline $\mathrm{IP}\left(\right.$ ng.m $\left.\mathrm{m}^{-3}\right)$ & 0.03 & $(0.02)$ & 0.08 & $(0.05)$ & 0.69 & $(0.27)$ & 2.16 & (1.83) & 0.30 & $(0.20)$ & 0.74 & $(0,58)$ \\
\hline $\operatorname{COR}\left(\mathrm{ng} \cdot \mathrm{m}^{-3}\right)$ & 0.01 & $(0.01)$ & 0.07 & $(0.04)$ & 0.21 & $(0.14)$ & 1.41 & $(1.40)$ & 0.09 & $(0.07)$ & 0.21 & $(0,22)$ \\
\hline$\Sigma\left(\text { ng. } m^{-3}\right)^{d}$ & 0.7 & $(0.3)$ & 1.3 & $(0.4)$ & 9.7 & $(4.0)$ & 47.6 & $(42.4)$ & 3.5 & $(1.2)$ & 18.4 & (19.1) \\
\hline$\Sigma^{\prime}\left(\text { ng. } m^{-3}\right)^{\mathrm{e}}$ & 0.3 & $(0.2)$ & 0.7 & $(0.3)$ & 6.4 & $(2.5)$ & 22.8 & $(16.7)$ & 2.3 & $(0.7)$ & 8.8 & (8.6) \\
\hline $\operatorname{PM} 10\left(\mu \mathrm{g} \cdot \mathrm{m}^{-3}\right)^{\mathrm{b}}$ & 18.9 & $(14.0)$ & 28.0 & $(4.2)$ & 12.9 & (5.1) & 24.3 & (12.8) & 12.6 & (7.3) & 13.1 & (5.1) \\
\hline $\mathrm{EC}\left(\mu \mathrm{g} \cdot \mathrm{m}^{-3}\right)$ & & $\mathrm{nd}^{\mathrm{f}}$ & 2.0 & $(0.7), n=27$ & 1.5 & $(0.6), n=41$ & 4.8 & (3.2), $n=41$ & 0.7 & $(0.4), n=42$ & 1.3 & $(0.8), \mathrm{n}=41$ \\
\hline $\mathrm{OC}\left(\mu \mathrm{g} \cdot \mathrm{m}^{-3}\right)$ & & nd & 9.6 & (3.2), $n=27$ & 7.4 & (2.3), $\mathrm{n}=41$ & 13.7 & (5.3), $n=41$ & 4.2 & $(2.0), n=42$ & 12.2 & $(4.8), n=41$ \\
\hline$(\mathrm{BghiP}+\mathrm{COR}) / \Sigma^{\prime}$ & $13 \%$ & (3) & $28 \%$ & (4) & $13 \%$ & (5) & $22 \%$ & (5) & $15 \%$ & (3) & $12 \%$ & (6) \\
\hline$(\mathrm{BbF}+\mathrm{BkF}) / \Sigma^{\prime}$ & $25 \%$ & (3) & $22 \%$ & (2) & $24 \%$ & (5) & $18 \%$ & (3) & $24 \%$ & (3) & $23 \%$ & (3) \\
\hline $\mathrm{CHR} / \Sigma^{\prime}$ & $21 \%$ & (3) & $15 \%$ & (2) & $14 \%$ & (4) & $14 \%$ & (4) & $16 \%$ & (2) & $19 \%$ & (5) \\
\hline
\end{tabular}

a: Excluding Saharan dust episode (see text);

b: TEOM (R\&P) measurements, data acquisition frequency: see text;

c: average value (standard deviation), $n=$ number of samples;

d: Sum of all PAHs;

e: Sum of all PAHs, except FLA and PYR;

f: not determined

winter, Table 2) are of the same order of magnitude as those observed in large European cities, such as Munich (Kiss et al., 1998), Rome (Cecinato et al., 1999; Menichini et al., 1999), Naples (Caricchia et al., 1999), London (Dimashki et al., 2001) or Paris (Pistikopoulos et al., 1990a), despite the much smaller human populations in the valleys. During summer (for all sites) and winter (at M1, M2 and C2), the concentrations are comparable to those of moderately polluted urban areas. The concentrations at the suburban area of Chamonix (C1) during winter (47.6 ng. $\mathrm{m}^{-3}$ ) are representative of strongly polluted atmospheres.

Several factors regulate the concentrations of PAH and their evolution in the valleys. The impact of the proximity of the sampling sites from potential sources is underlined by the differences between urban background sites (M1 and C1) and near-city background sites (M2 and $\mathrm{C} 2$ ), with concentrations being about 2.5 times higher in the former sites, for both valleys (Table 2). This underlines the role of local emission sources, as opposed to transport from outside of the valleys, in influencing PAH concentrations.
Strong seasonal variations can also be observed at the urban sites $\mathrm{M} 1$ and $\mathrm{C} 1$. The increase in $\Sigma$ is larger in the Chamonix valley, exhibiting a winter/summer ratio of 36 , whereas the ratio is about 14 in the Maurienne valley. It is not uncommon to observe such seasonal variations, but with a winter/summer ratio ranging between 4 and 10 (Carrichia et al., 1999; Menichini et al., 1999; Dörr et al., 1996; Harrisson et al., 1996; Halshall et al., 1994; Aceves and Grimalt, 1993; Kiss et al., 1998). Higher ratios in our case can probably be explained by the cumulative effects of several processes:

- First, higher ratios result from additional emissions, particularly with residential heating as a new source in winter. This is clearly seen in the evolution of the $\Sigma / \mathrm{PM}_{10}$ ratio between seasons, with values being about 30 times higher in winter than in summer in both valleys, indicating a stronger impact by combustion sources on the composition of aerosol during winter.

- Second, seasonal variability can be linked with the shift of the Gas/Particles partitioning toward the particulate 


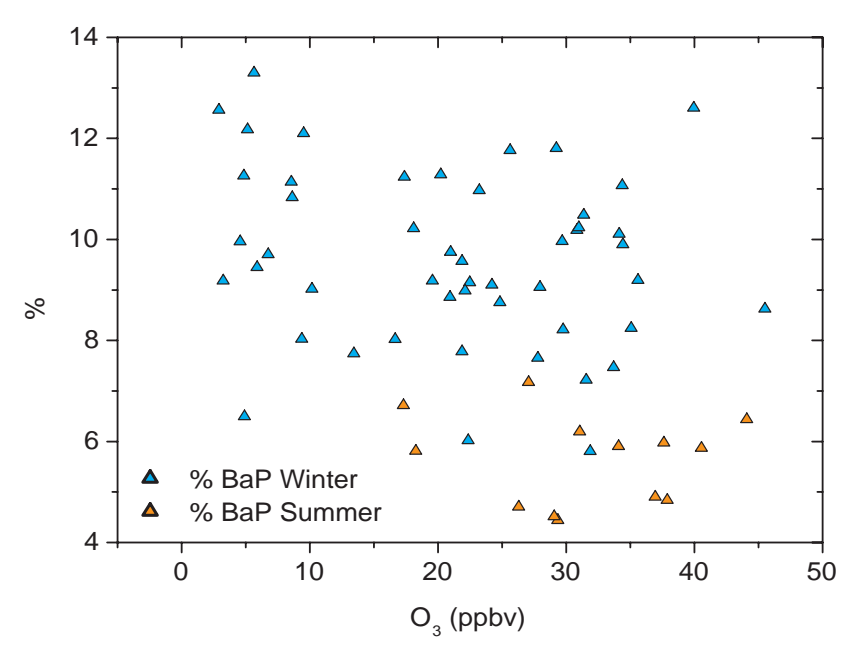

Fig. 3. $\mathrm{BaP} / \Sigma^{\prime}$ versus $\mathrm{O}_{3}$ concentration.

phase, as induced by the temperature decrease (Pankow and Bildeman, 1992). This decrease is rather large in the valleys; for example, average temperatures of $18.0^{\circ} \mathrm{C}$ and $-2.5^{\circ} \mathrm{C}$ were recorded over the sampling weeks in Chamonix (Table 2) during summer and winter, respectively. Nevertheless, as discussed above, Gas/Particle partitioning does not appear to be a fundamental factor governing PAH concentrations, except for FLA and PYR. In addition, the $\Sigma^{\prime}$ winter/summer ratios are 21 and 32 at $\mathrm{M} 1$ and $\mathrm{C} 1$, respectively. These ratios are thus very close to those calculated when considering $\Sigma$. Therefore, Gas/Particle partitioning does not appear to have a significant influence on the seasonal variations of total PAH concentration.

- Third, degradation processes are less pronounced in winter, leading to some accumulation of reactive compounds. This can be illustrated by considering the evolution of $\mathrm{BaP}$ and $\mathrm{BaA}$ concentrations, with both species being considered the most reactive PAHs in the particulate phase (Kamens et al., 1990). In our case, BaP and $\mathrm{BaA}$ present the largest winter/summer ratios (57 and 51 at $\mathrm{C} 1$ and 44 and 30 at M1, respectively), while other PAHs are characterized by winter/summer ratios in the range of 21 to 43 at $\mathrm{C} 1$ and 7 to 21 at M1. This variability between reactive and less-reactive PAHs reflects the impact of degradation processes on the seasonal variations of the total concentration. However, chemical degradations occurring during the collection of samples should not be neglected. Recently, results obtained by Tsapakis et al. (2003) showed that $27 \%$ of the total PAH concentration in the particle phase can be lost by ozone degradation occurring during sampling (24h Hi-Vol sampling; average ozone concentration: $58 \mathrm{ppbv})$. For example, $\mathrm{O}_{3}$ degradation can lead to a loss ranging from 42 to $55 \%$ for $\mathrm{BAP}$, the most re- active PAH. However, in an atmosphere characterized by low $\mathrm{O}_{3}$ levels ( $27 \mathrm{ppbv}$ ), losses induced by reactivity do not substantially affect particulate PAH concentrations for 24h Hi-Vol samplings (Tsapakis et al., 2003). During the POVA intensive sampling periods, $\mathrm{O}_{3}$ concentration ranged between 3 and $45 \mathrm{ppbv}$ in winter, and between 17 and $44 \mathrm{ppbv}$ in summer (mean concentration: $21.2 \mathrm{ppbv}$ during winter, and $31.5 \mathrm{ppbv}$ during summer). Thus, particulate PAH concentrations should not be altered significantly by $\mathrm{O}_{3}$ degradation. In addition, as shown in Fig. 3, no correlations can be found between relative concentrations of $\mathrm{BaP}$ and $\mathrm{O}_{3}$ concentrations. Therefore, reactions between $\mathrm{PAH}$ and $\mathrm{O}_{3}$ occurring during the collection do not appear to be a fundamental factor governing PAH concentrations during our study. Thus, seasonal variations of total PAH concentrations are partly explained by atmospheric degradation processes.

- Lastly, a final factor concerns changes in atmospheric dynamics, especially the formation of inversion layers. The formation of inversion layers is not specific to mountainous systems, but they are more frequent and stronger in this type of environment, where direct sunshine can be very limited in winter due to steep-sided valleys (Anquetin et al., 1999).

Both seasons are also characterized by stronger PAH concentrations in the valley of Chamonix (1.3 and $47.6 \mathrm{ng} . \mathrm{m}^{-3}$ at $\mathrm{C} 1$ during summer and winter, respectively) than in the valley of Maurienne (0.7 and 9.7 ng.m ${ }^{-3}$ at M1 during summer and winter, respectively), despite very large heavy-duty international traffic in the latter valley. Average $\Sigma$ ratios between the two valleys are close to 2 and 5 during the summer and winter, respectively. Therefore, heavy-duty traffic does not appear to be the fundamental parameter governing PAH concentrations. The influences of other sources, and of dilution and dispersion processes, seem to play a more dominant role. In this respect, the larger ventilation in the much-wider Maurienne Valley is most probably one of the key factors decreasing concentrations through dispersion.

Figure 4 presents the average ratio of each PAH measured with respect to $\Sigma^{\prime}$, for all sites and seasons. None of these average profiles is fundamentally different from the others, while the sampling sites are characterized by different sources and conditions (near-city background or urban sites, winter or summer). Quantitative source apportionment using Chemical Mass Balance models based only on PAH therefore appears quite difficult. However, as mentioned in Sect. 3, a qualitative study can be performed if taking into consideration both the contribution of specific PAHs (CHR) or $\mathrm{PAH}$ groups $(\mathrm{BghiP}+\mathrm{COR}, \mathrm{BkF}+\mathrm{BbF})$. Average values of the specific contributions of BghiP+COR, BbF+BkF, and CHR to $\Sigma^{\prime}$ are presented in Table 2 . T-tests were performed to evaluate the differences in means between each of these 
data sets. All average values discussed below can be considered as statistically different ( $\mathrm{p}$-level $<0.05)$, except those mentioned in the text. In both seasons, the most important $(\mathrm{BghiP}+\mathrm{COR}) / \Sigma^{\prime}$ ratio is observed in the urban background site of the Chamonix valley. In addition, this ratio, being indicative of the impact of emissions from gasoline-powered vehicles, decreases significantly between summer and winter with values varying from $28 \%$ to $22 \%$ (Table 2 ). All other sampling sites show the same $(\mathrm{BghiP}+\mathrm{COR}) / \Sigma^{\prime}$ ratio, even for M1, the urban background site of the Maurienne valley $(13 \%$ at $\mathrm{M} 1,15 \%$ at $\mathrm{M} 2$ and $12 \%$ at $\mathrm{C} 2)$. Furthermore, the $(\mathrm{BbF}+\mathrm{BkF}) / \Sigma^{\prime}$ ratio, being indicative of emissions from diesel vehicles and to some extent of wood burning, does not show high variability between sites and seasons. As a first approach, the higher values systematically recorded in the Maurienne Valley (24-25\%) could lead to the conclusion that diesel vehicles are the main PAH source in this valley, regardless of season. In the Chamonix valley, the $\mathrm{BbF}+\mathrm{BkF}$ contribution in winter is more important in the near-city background site (23\% at $\mathrm{C} 2$ and $18 \%$ at $\mathrm{C} 1$ ). In addition, the $\mathrm{C} 1$ site in summer showed an increased $\mathrm{BbF}+\mathrm{BkF}$ contribution of up to $22 \%$. These results could be the consequence of both the strong influence of gasoline vehicle emissions in the urban background site and a more important impact of wood burning in the near-city $\mathrm{C} 2$ site.

These hypotheses obtained from our study of two PAH ratios are supported by the values of the relative concentrations of CHR. This compound is emitted in strong amounts by wood combustion and also shows significant emission rates from diesel sources. As no biomass or agricultural fires were observed during summer, differences in $\mathrm{CHR} / \Sigma^{\prime}$ ratio between $\mathrm{C} 1$ and M1 indicate the larger influence of diesel exhaust in the Maurienne valley. In winter, larger values are observed in the more rural site (16 and 19\% at M2 and C2, respectively), and are in agreement with the stronger influences of wood burning at these sampling sites. However, it should be noted that the average values of $\mathrm{CHR} / \Sigma^{\prime}$ calculated at M1 and M2 only show a weak statistical difference (p-level=0.33).

Further evaluations of these hypotheses can be gained by considering other anthropogenic indicators, such as EC, OC or NO, and by studying the temporal evolution of concentrations during the sampling periods.

\subsection{Temporal evolutions}

\subsubsection{Summer campaign}

Figure 5 presents the evolution of the daily total concentration of PAH ( $\Sigma$ for sites C1 and M1 during the summer campaign, together with the evolution of concentrations of $\mathrm{NO}$ and $\mathrm{NO}_{2}$. This figure also presents the variations of the ratios $(\mathrm{BghiP}+\mathrm{COR}) / \Sigma^{\prime}$ and $(\mathrm{BbF}+\mathrm{BkF}) / \Sigma^{\prime}$.

The total PAH concentrations in the Chamonix Valley are rather constant throughout the week, except for Friday 18th
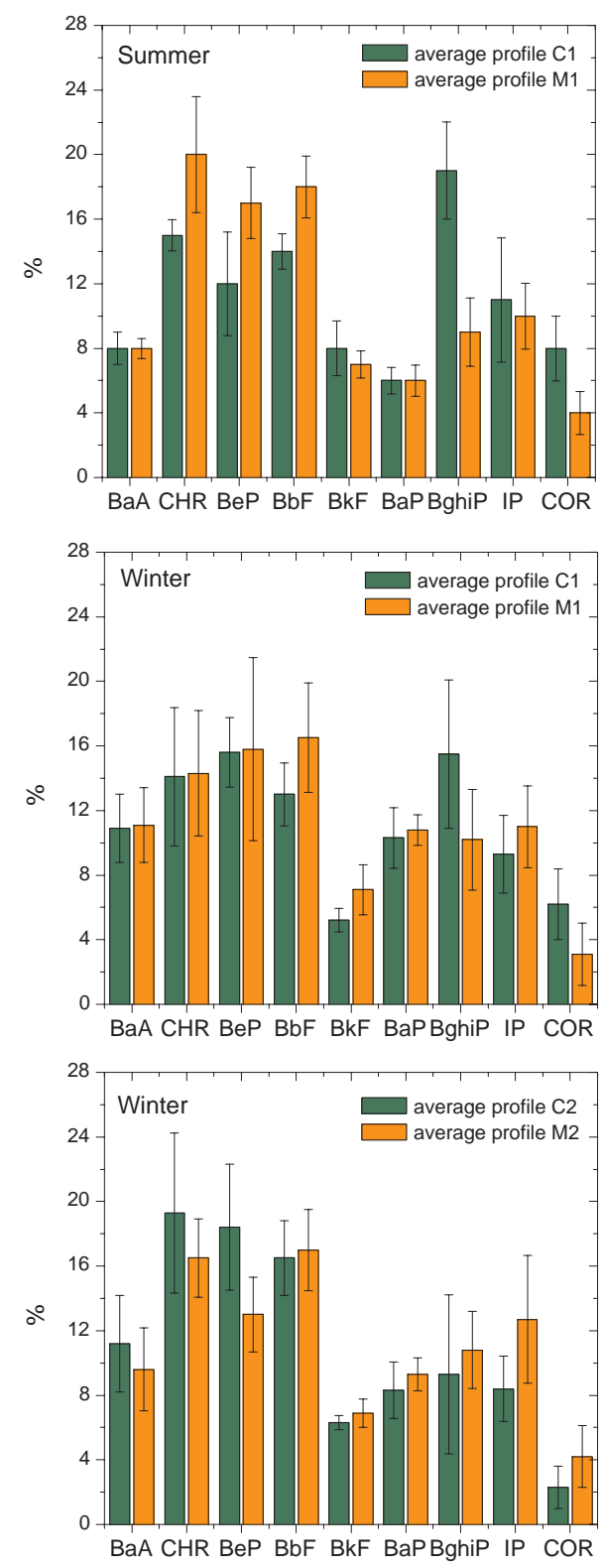

Fig. 4. Average PAH chemical profiles. Relative concentrations are calculated for the ratio of individual PAH with the total PAH concentration $\Sigma^{\prime}$.

and Sunday 20th on which maximum and minimum values are measured, respectively. On Sunday, the lower activity near the sampling site can explain the decrease in concentration, as is usually observed for primary pollutants such as NO (Fig. 5). The sharp increase in concentrations on Friday is also characterized by a higher concentration of NO and higher relative concentrations of heavy PAHs (BghiP and COR)(Fig. 5). At the same time, wind speed and direction measured at the local meteorological station also indicated very light winds at ground level. Thus, the strong increase in PAH concentration is related to an increase in vehicular 


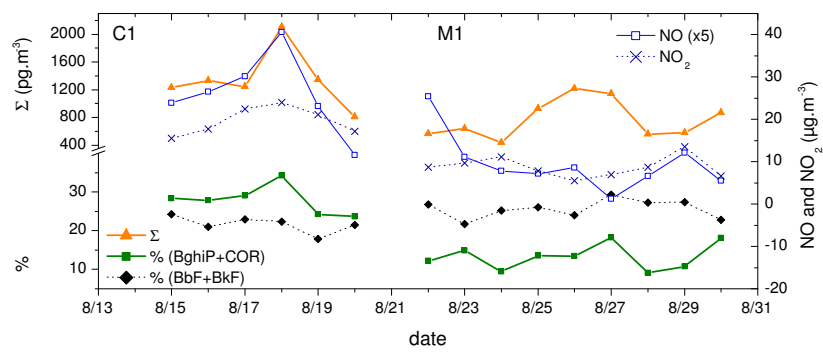

Fig. 5. Evolution of $\Sigma$, $\mathrm{NO}(x 5)$ and $\mathrm{NO}_{2}$ concentrations, relative concentration of $\mathrm{BghiP}+\mathrm{COR}$ and $\mathrm{BF}(\mathrm{BbF}+\mathrm{BkF})$ during the summer campaign at $\mathrm{C} 1$ and $\mathrm{M} 1$ sites.

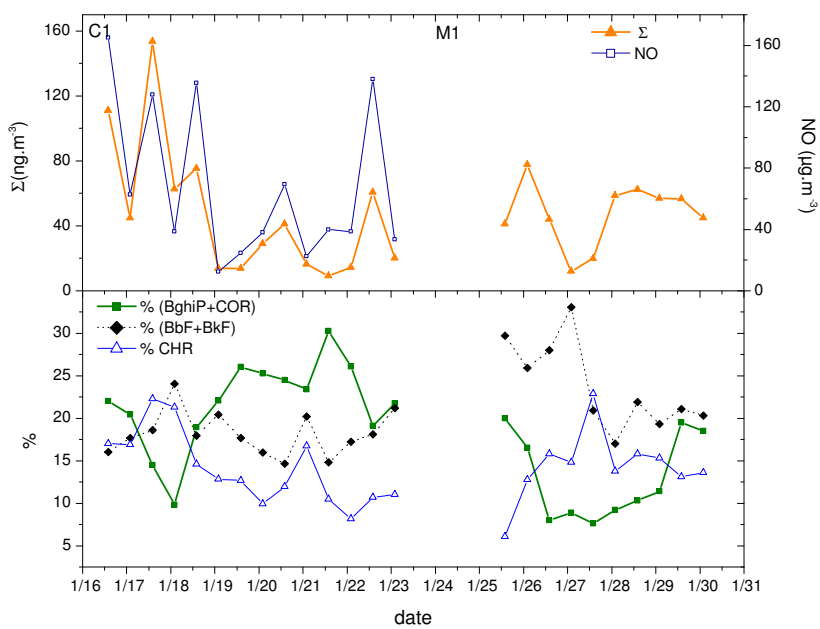

Fig. 6. Evolution of $\Sigma$ and NO concentrations and of relative concentrations of BghiP+COR, BbF+BkF and $\mathrm{CHR}$ at $\mathrm{C} 1$ and $\mathrm{M} 1$ during the winter campaign.

emissions near the sampling site, and is supported by limited dispersion/dilution processes.

From a more general point of view, Fig. 5 shows strong co-variations between $\Sigma, \mathrm{NO}$ and the $(\mathrm{BghiP}+\mathrm{COR}) / \Sigma$ ratio at the urban site of the Chamonix Valley (C1) during the overall sampling period, while the contribution of Benzofluoranthenes $(\mathrm{BbF}+\mathrm{BkF})$ is nearly constant. Therefore, gasoline emissions appear to be the main source of PAHs in the Chamonix Valley, confirming the interpretation proposed from average values. Further analysis shows that the Pearson correlation coefficient between $\Sigma$ and $\mathrm{NO}(\mathrm{r}=0.93)$ is better than that calculated between $\Sigma$ and $\mathrm{NO}_{2}$ (r=0.69). Thus, the influence of proximity sources appears predominant. In addition, we observe strong correlations between $\Sigma$, EC and OC ( $\Sigma$ vs. OC: $\mathrm{r}=0.93 ; \Sigma$ vs. EC: $\mathrm{r}=0.79$ ), but no correlations between the organic fractions and $\mathrm{PM}_{10}\left(\Sigma\right.$ vs. $\mathrm{PM}_{10}: \mathrm{r}=-0.1 ; \mathrm{OC}$ vs. $\left.\mathrm{PM}_{10}: \mathrm{r}=0.14\right)$. These results suggest an external mixing of the particles constituting the $\mathrm{PM}_{10}$ mass, and an organic fraction strongly influenced by primary anthropogenic sources.

Total concentrations show more variability in the Maurienne Valley (Fig. 5). The highest $\Sigma$ values were obtained

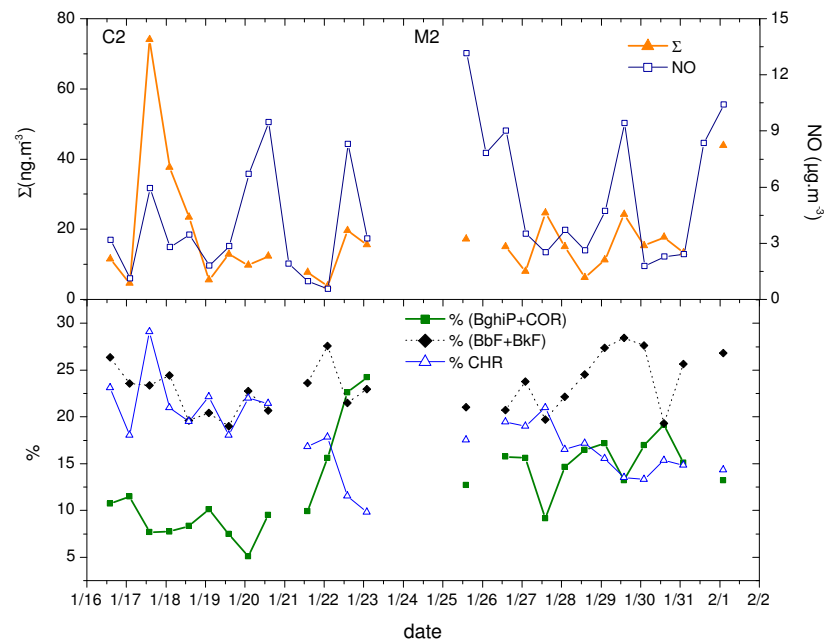

Fig. 7. Evolution of $\Sigma$ and NO concentrations and of relative concentrations of BghiP+COR, $\mathrm{BF}(\mathrm{BbF}+\mathrm{BkF})$ and $\mathrm{CHR}$ at $\mathrm{C} 2$ and $\mathrm{M} 2$ during the winter campaign. $\Sigma$ is multiplied by 5 for the M1 and M2 sites.

on Saturday (26 August) and Sunday (27 August). However, these two days were also characterized by a strong episode of Saharan dust associated with anthropogenic inputs, most probably with an origin from the heavily industrialized Torino area in Italy, as discussed in Colomb et al. (2002) and Aymoz et al. (2004). Except for these 2 days, the highest PAH concentrations are observed on Wednesdays (23 and 30 August). As mentioned in Sect. 2.1, this day represents the day of maximum heavy-duty traffic on the highway in the valley, with an average of 6000 trucks per day. These concurrent maxima are therefore in good agreement with the discussion based on average values, indicating the large impact of diesel emissions in the Maurienne Valley. However, the temporal variations of PAH ratios show some discrepancies with this initial interpretation. While the contributions of $\mathrm{BbF}$ and $\mathrm{BkF}$ to $\Sigma$ are higher than those of BghiP and COR, total PAH concentrations show a better correlation to the ratio $(\mathrm{BghiP}+\mathrm{COR}) / \Sigma^{\prime}$. Therefore, the variations of PAH concentrations seem to be linked to changes in the gasoline source, with a constant impact from diesel sources. Further work is needed to reconcile these two sets of observations. Finally, as opposed to observations in the Chamonix valley, $\Sigma$ values are not correlated in the Maurienne valley with either $\mathrm{NO}(\mathrm{r}=-0.32)$ or $\mathrm{NO}_{2}(\mathrm{r}=-0.38)$ (Fig. 5). This situation most probably shows the efficiency of dispersion mechanisms between sources and sampling sites in this valley at that time of the year.

\subsubsection{Winter campaign}

Figures 6 and 7 present the temporal evolution of total PAH concentrations together with the evolution of $\mathrm{NO}$ for each of the 12-h sampling periods at urban (C1 and M1) and rural 
Table 3. Pearson correlation coefficients between $\Sigma$, PM10, OC, EC and NO at the C1 and C2 (Valley of Chamonix) sites during winter. Meteorological periods are described in the text. Pearson coefficients calculated with 6 and 8 points for periods 1 and 2, respectively.

\begin{tabular}{cccccc}
\hline C1 & & & & & \\
\hline Period 1 & $\Sigma$ & PM10 & OC & EC & NO \\
\hline$\Sigma$ & 1 & & & & \\
PM10 & 0.971 & 1 & & & \\
OC & 0.966 & 0.956 & 1 & & \\
EC & 0.783 & 0.779 & 0.833 & 1 & \\
NO & 0.654 & 0.578 & 0.678 & 0.933 & 1 \\
\hline & & & & & \\
\hline Period 2 & $\Sigma$ & PM10 & OC & EC & NO \\
\hline$\Sigma$ & 1 & & & & \\
PM10 & 0.956 & 1 & & & \\
OC & 0.971 & 0.953 & 1 & & \\
EC & 0.933 & 0.946 & 0.936 & 1 & \\
NO & 0.921 & 0.900 & 0.925 & 0.979 & 1 \\
\hline
\end{tabular}

sites (C2 and M2), respectively. These figures also present the variation of the ratios $(\mathrm{BghiP}+\mathrm{COR}) / \Sigma^{\prime},(\mathrm{BbF}+\mathrm{BkF}) / \Sigma^{\prime}$ and $\mathrm{CHR} / \Sigma^{\prime}$.

In the Chamonix valley, temporal evolution of $\Sigma$ at the two sites show strong variability throughout the week. This variability can be explained partly by the variation of meteorological parameters. During the first part of the campaign, from 16 to 18 January to (period 1), anticyclonic conditions prevailed with low temperature $\left(-4.5^{\circ} \mathrm{C}\right.$ on average) and low wind speed. Concentrations of PAH up to $150 \mathrm{ng} \cdot \mathrm{m}^{-3}$ are recorded at that time. Afterwards, from 19 to 22 January (period 2), different meteorological conditions occurred with more disturbed weather, higher temperatures $\left(-1.5^{\circ} \mathrm{C}\right.$ on average) and higher wind speeds. These conditions allow better dispersion of particles, leading to lower PAH concentrations. The influence of meteorological conditions can also be highlighted by correlations between $\Sigma$ and others parameters, such as EC, OC, and $\mathrm{PM}_{10}$ concentrations. Table 3 presents the correlations between $\Sigma, \mathrm{PM}_{10}, \mathrm{OC}, \mathrm{EC}$, and $\mathrm{NO}$ at the two sites for both meteorological periods. At site $\mathrm{C} 1$, the correlations between all these parameters are very strong during the 2 periods (ranging from 0.6 to 0.98 ). High correlations between $\Sigma, \mathrm{EC}$, and $\mathrm{NO}$ are relatively common in source areas, while a correlation between $\Sigma$ and $\mathrm{PM}_{10}$ is rather unusual ( $\mathrm{r}=0.971$ and 0.956 during period 1 and period 2 , respectively). PAHs are mainly associated with submicron particles (Venkataraman and Friedlander, 1994; SchnelleKreis et al., 2001; Aceves and Grimalt, 1993; Pistikopoulos et al., 1990b), a size range that generally represents only a small fraction of the $\mathrm{PM}_{10}$ mass balance. Since PAHs are primary anthropogenic compounds, such correlations indicate that $\mathrm{PM}_{10}$ concentrations result essentially from primary anthropogenic emissions, with marginal inputs consisting of natural aerosol. This is in good agreement with the very large

\begin{tabular}{cccccc}
\hline C2 & & & & & \\
\hline Period 1 & $\Sigma$ & PM10 & OC & EC & NO \\
\hline$\Sigma$ & 1 & & & & \\
PM10 & 0.986 & 1 & & & \\
OC & 0.912 & 0.962 & 1 & & \\
EC & 0.783 & 0.861 & 0.937 & 1 & \\
NO & 0.885 & 0.873 & 0.747 & 0.570 & 1 \\
\hline & & & & & \\
\hline Period 2 & $\Sigma$ & PM10 & OC & EC & NO \\
\hline$\Sigma$ & 1 & & & & \\
PM10 & 0.5251 & & & & \\
OC & 0.640 & 0.871 & 1 & & \\
EC & 0.519 & 0.674 & 0.667 & 1 & \\
NO & 0.647 & 0.659 & 0.509 & 0.587 & 1 \\
\hline
\end{tabular}

contribution of EC to $\mathrm{PM}_{10}$ (20\% on average) during these periods.

There are further differences between the two meteorological periods. First, the correlations between $\Sigma$, EC, and NO are lower during period 1 than period 2 at the urban site (C1) (Table 3), suggesting an "older" aerosol during the anticyclonic period. Also, despite similar correlation coefficients between $\Sigma$ and $\mathrm{PM}_{10}$, their ratio varies between the two periods (Fig. 8) at the C1 site; an accumulation of pollutants is again suggested during period 1, with larger relative concentrations of $\mathrm{PAH}$ in the $\mathrm{PM}_{10}$. Second, the same characteristics are also seen at the near-city $\mathrm{C} 2$ site during period 1, despite much lower concentrations; strong correlations (Table 3 ) between all the parameters and a $\Sigma / \mathrm{PM}_{10}$ ratio identical to that of the urban site suggest a contaminated air mass at the scale of the valley. During the second part of the sampling week, all of these correlations decrease significantly at $\mathrm{C} 2$, indicating a smaller direct impact from emission sources for this near-city site in perturbed meteorological conditions. During this period, PAH concentrations and $12 \mathrm{~h}$ average $\mathrm{PM}_{10}$ concentrations show low variability, preventing the accurate calculation of ratios (Fig. 8).

In the Maurienne valley, two meteorological periods can also be observed. A first period (period 3), from 25 to 27 January, is characterized by a disturbed episode with some precipitation and relatively strong NE-SW winds. During the last part of the campaign, from 28 to 31 January (period 4), anticyclonic conditions prevailed with low temperatures and low wind speeds mainly from the SW-NE. As opposed to the valley of Chamonix, total PAH concentrations in the Maurienne valley do not show very large evolutions between these two periods (Figs. 6 and 7). Furthermore, no significant correlations are observed at the M1 site between $\Sigma, \mathrm{EC}$, or $\mathrm{PM}_{10}$ (NO was not measured at this site) for any of 


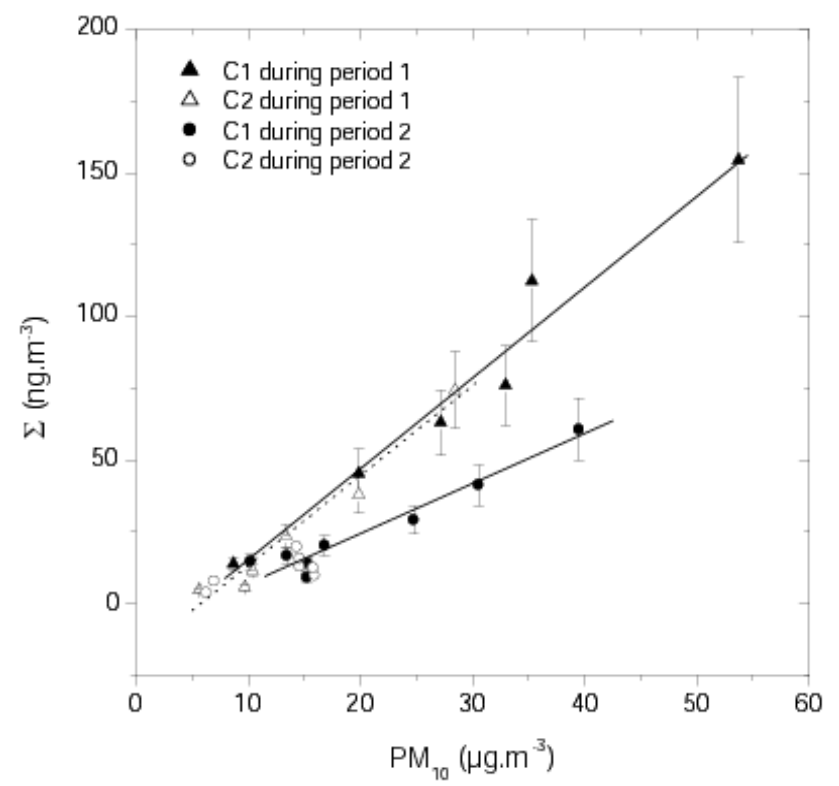

Fig. 8. Correlations between the total PAH concentrations and PM10 obtained in the Chamonix valley for the $\mathrm{C} 1$ and $\mathrm{C} 2$ sampling sites during the winter campaign.

the periods. This may reflect the complexity of the sources contributing to $\mathrm{PM}_{10}$ at that site. At Orelle (M2), no significant correlations are observed during period 3 , while strong correlations appear during period 4 (Table 4 ) between $\Sigma, \mathrm{EC}$, $\mathrm{NO}$, and $\mathrm{PM}_{10}$, indicating the impact of local combustion sources on these conditions.

Therefore, under winter conditions, the strong PAH levels observed in the two valleys, and especially in the Chamonix valley, are generated by internal sources. Under these specific conditions, the study of the capability of PAHs to allow discrimination of sources is particularly interesting. In the Chamonix valley, the ratios $(\mathrm{BbF}+\mathrm{BkF}) / \Sigma^{\prime}$ and $\mathrm{CHR} / \Sigma^{\prime}$ show good covariations at the two sites, especially at the near-city site (Fig. 7). It can be postulated that BbF, BkF and CHR are emitted predominantly by wood combustion sources. The importance of this source is confirmed by the presence in large quantities of guaiacyl and syringyl derivatives in our samples. These compounds come from the thermal breakdown of lignin, and are indicators of wood combustions (Nolte et al., 2001). These results will be discussed in a future publication.

In the Maurienne valley, where mixing sources and important dilution/dispersion processes have been highlighted, the study of temporal evolution of these three $\mathrm{PAH}$ ratios is complex. No correlations are observed between $(\mathrm{BbF}+\mathrm{BkF}) / \Sigma^{\prime}$, $\mathrm{CHR} / \Sigma^{\prime}$, (BghiP+COR) $/ \Sigma^{\prime}$, and $\Sigma$ (Figs. 6 and 7), underlining the influence of multiples sources and processes in governing PAH concentrations. Examinations of these specific ratios are therefore insufficient for the determination of PAH sources.
Table 4. Pearson correlation coefficients between $\Sigma$, PM10, OC, $\mathrm{EC}$, and NO at the M2 (Maurienne Valley) site during the winter campaign. Meteorological periods are described in the text. Pearson coefficients calculated for 5 and 7 points for periods 3 and 4 , respectively.

\begin{tabular}{cccccc}
\hline M2 & & & & & \\
\hline Period 3 & $\Sigma$ & PM10 & OC & EC & NO \\
\hline$\Sigma$ & 1 & & & & \\
PM10 & 0.128 & 1 & & & \\
OC & 0.928 & 0.833 & 1 & & \\
EC & 0.318 & 0.650 & 0.647 & 1 & \\
NO & 0.197 & -0.120 & 0.519 & 0.904 & 1 \\
\hline & & & & & \\
\hline Period 4 & $\Sigma$ & PM10 & OC & EC & NO \\
\hline$\Sigma$ & 1 & & & & \\
PM10 & 0.886 & 1 & & & \\
OC & 0.696 & 0.940 & 1 & & \\
EC & 0.685 & 0.866 & 0.931 & 1 & \\
NO & 0.812 & 0.928 & 0.890 & 0.753 & 1 \\
\hline
\end{tabular}

\section{Conclusions}

The study of PAH concentrations and speciation in the context of these alpines valleys highlights several interesting pieces of information. First, it shows the large impact of local sources to the contamination of the atmosphere. This impact is much larger in winter than in summer, with an increasing contribution of local combustion sources to the formation of $\mathrm{PM}_{10}$. This increase from one season to the other is larger than generally observed in other types of environments. It is partly due to additional sources, but is also very much enhanced by local meteorology. All of these conditions can lead to PAH concentrations in the range of several tens of ng. $\mathrm{m}^{-3}$, comparable to those observed in large cities. The current levels show that it will be challenging to meet potential new EU standards in this environment. The current proposition of the directive is based on a target value of $1 \mathrm{ng} . \mathrm{m}^{-3}$ on an annual average for BaP, while the UK government Expert Panel on Air Quality Standard has set a UK air quality standard of $0.25 \mathrm{ng} . \mathrm{m}^{-3}$ for the same species (Dimashki et al., 2001).

Second, our results show that PAH concentrations were higher in the Chamonix valley than in the Maurienne valley, in a context involving the absence of international heavyduty traffic in the former valley. This sensitivity is probably related both to the morphological differences between these valleys, with more ventilation occurring in the wider Maurienne Valley, and to the importance of wood combustion sources in the Chamonix Valley. It will be interesting to compare these results for the second set of field campaigns 
proposed in the POVA program, undertaken with the "Tunnel du Mont Blanc" reopened to international traffic.

Third, an additional goal of this study was to investigate the ability of PAH signatures to allow the discrimination of different combustion sources in an environment that is simpler than that of large urban areas. Examinations of the relative concentrations of several PAHs (BghiP, COR, BbF, BkF, and $\mathrm{CHR}$ ) and their evolutions provide a qualitative interpretation of aerosol sources that is in general agreement with our knowledge of these sources in the valleys. However, differences remain small (between valleys, sites, and seasons). Considering the variability of the different relative emission rates proposed in the literature, the use of $\mathrm{PAH}$ alone in a quantitative study (using a CMB approach, for example) on the influence of sources seems rather dubious. Further work in this direction is in progress, using other molecular markers, including wood combustion tracers.

Acknowledgements. The program POVA is supported in France by the Région Rhône Alpes, ADEME (Agence de l'Environnement et de la Maîtrise de l'Energie), METL (Ministère de l'Equipement, des Transports et du Logement), MEDD (Ministère de l'Ecologie et du Développement Durable), and Primequal 2. We would like to thank Météo France for providing the meteorological data, and SFTRF, ATMB and DDE de Savoie and Haute Savoie for providing the traffic data. We are indebted to W. Maenhaut (INW, Gent, Belgium) for facilities for analyzing EC/OC samples, and l'Air de L'Ain et des Pays de Savoie (Air APS, http://www.atmo-rhonealpes.org/air2savoie/) for NOx and TEOM measurements and for providing the cartography of the valleys (Fig. 1).

Edited by: J. Abbatt

\section{References}

Aceves, M. and Grimalt, J. O.: Seasonally dependent size distributions of aliphatic and polycyclic aromatic hydrocarbons in urban aerosols from densely populated areas, Environ. Sci. Technol., 27, 2896-2908, 1993.

Anquetin, S., Guilbaud, C., and Chollet, J. P.: Thermal valley inversion impact on the dispersion of a passive pollutant in a complex mountainous area, Atmos. Environ., 33, 3953-3959, 1999.

Aymoz, G., Jaffrezo, J. L., Jacob, V., Colomb, A., and George, C.: Evolution of organic and inorganic components of aerosol during a Saharan dust episode observed in the French Alps, Atmos. Chem. Phys. Discuss., 4, 3875-3909, 2004.

Besombes, J. L., Maître, A., Patissier, O., Marchand, N., Chevron, N., Stoklov, M., and Masclet, P.: Particulate PAHs observed in the surrounding of a municipal incinerator, Atmos. Environ., 35, 6093-6104, 2001.

Birch, M. E. and Cary, R. A.: Elemental Carbon-Based Method for Monitoring Occupational Exposures to Particulate Diesel Exhaust, Aerosol Sci. Technol. 25, 221-241, 1996.

Caricchia, A. M., Chiavarini, S., and Pezza, M.: Polycyclic aromatic hydrocarbons in the urban atmospheric particulate matter in the city of Naples (Italy), Atmos. Environ., 33, 3731-3738, 1999.
Cecinato, A., Marino, F., Di Filippo, P., Lepore, L., and Possanzini, M.: Distribution of n-alkanes, polynuclear aromatic hydrocarbons between the fine and coarse fractions of inhalable atmospheric particles. J. Chromatogr. A, 826, 255-264, 1999.

Colomb, A., Jacob, V., Debionne, J. L., Aymoz, G., and Jaffrezo, J. L.: VOC's evolution during a Saharan dust episode in an alpine valley in August 2000, Fresenius Environ. Bull., 11(8), 441-453, 2002.

Combet, E., Jarosz, J., Martin-Bouyer, M., Paturel, L., and Saber, A.: Mesure par spectrofluorimetrie Shpo'skii des émissions unitaires en HAP de 30 véhicules légers à essence et diesels selon huit cycles représentatifs, Sci. Total Environ., 134, 147-160, 1993.

Dachs, J., Bayona, J. M., Fowler, S. W., Miquel, J. C., and Albaiges, J.: Vertical fluxes of polycyclic aromatic hydrocarbons and organochlorides in the western Alborean Sea (South-western Mediterranean), Mar. Chem., 52, 75-86, 1996.

Dimashky, M., Lee, H. L., Harrison, R. M., and Harrad, S.: Temporal trends, temperature dependence, and relative reactivity of atmospheric polycyclic aromatic hydrocarbons, Environ. Sci. Technol., 35, 2264-2267, 2001.

Dörr, G., Hippelein, M., Kaupp, H., and Hutzinger, O.: Baseline contamination assessment for a new resource recovery facility in Germany: Part VI: Levels and profiles of polycyclic aromatic hydrocarbons (PAH) in ambient air, Chemosphere, 33, 1569-1578, 1996.

Duran, A., De Lucas, A., Carmona, M., and Ballesteros, R.: Simulation of atmospheric PAH emissions from diesel engines, Chemosphere, 44, 921-924, 2001.

Freeman, D. J. and Catell, C. R.: Woodburning as a source of atmospheric polycyclic aromatic hydrocarbons, Environ. Sci. Technol., 24, 1581-1585, 1990.

Halsall, C. J., Coleman, P. J., Davis, B. J., Burnett, V., Waterhouse, K. S., Harding-Jones, P., and Jones, K. C.: Polycyclic aromatic hydrocarbons in UK urban air, Environ. Sci. Technol., 28, 2380 2386, 1994.

Harrison, R. M., Smith, D. J. T., and Luhana, L.: Source apportionment of polycyclic aromatic hydrocarbons collected from an urban location in Birmingham, UK Environ. Sci. Technol., 30, 825-832, 1996.

Hering, S. V., Miguel, A. H., and Dod, R. L.: Tunnel measurements of the PAHs, carbon thermogram and elemental source signature for vehicular exhaust, Sci. Total Environ., 36, 39-52, 1984.

IARC: Polynuclear aromatic compounds, Part 1, Chemical, environmental and experimental datas, In: IARC Monographs on the Evaluation of Carcinogenic Risk of Chemicals to Humans, Vol 32, International Agency for Research on Cancer, Lyon, 1983.

IARC: Overall evaluations of carcinogenicity an updating of IARC monographs, In: IARC monographs on the evaluation of carcinogenic risk of chemicals to humans, Vol. 1-42 (Suppl 7). International Agency for Research on Cancer, Lyon, 1987.

Jenkins, B. M., Jones, A. D., Turn, S. Q., and Williams, R. B.: Emission factors for polycyclic aromatic hydrocarbons from biomass burning, Environ. Sci. Technol., 30, 2462-2469, 1996.

Kavouras, I. G., Koutrakis, P., Tsapakis, M., Lagoudaki, E., Stephanou, E. G., Von Baer, D., and Oyola, P.: Source apportionment of urban particulate aliphatic and polynuclear aromatic hydrocarbons using multivariable methods, Environ. Sci. Technol., 35, 2288-2294, 2001. 
Khalili, N. R., Scheff, P. A., and Holsen, T. M.: PAH source fingerprints for coke ovens, diesel and gasoline engines, highway tunnels, and wood combustion emissions, Atmos. Environ., 29, 533-542, 1995.

Kamens, R. M., Guo, J., Guo, Z., and McDow, S. R.: Polynuclear aromatic hydrocarbon degradation by heterogeneous reactions with $\mathrm{N}_{2} \mathrm{O}_{5}$ on atmospheric particles, Atmos. Environ., 24A, 1161-1173, 1990.

Kiss, G., Varga-Puchony, Z., Rohrbacher, G., and Hlavay, J.: Distribution of polycyclic aromatic hydrocarbons on atmospheric aerosol particles of different sizes, Atmos. Res., 46, 253-261, 1998.

Larssen, S., Sluyter, R., and Helmis, C.: Criteria for EUROAIRNET, the EEA air quality monitoring and information network, EEA Technical Report, http://reports.eea.eu.int/TEC12/en, 1999.

Li, C. K. and Kamens, R. M.: The use of polycyclic aromatic hydrocarbons as sources signatures in receptor modeling, Atmos. Environ., 27A, 523-532, 1993.

Li, H., Banner, C. D., Mason, G. G., Westerholm, R. N., and Rafter, J. J.: Determination of polycyclic aromatic compounds and dioxin receptor ligands present in diesel exhaust particulate extracts, Atmos. Environ., 30, 3537-3543, 1996.

Marchand, N.: Etude de la composante organique de l'aérosol atmosphérique: cas de deux vallées alpines (Chamonix et Maurienne) et développement analytique, $\mathrm{PhD}$ thesis, Université de Savoie, (in French), 2003.

Marr, L. C., Kirchstetter, T. W., Harley, R. A., Miguel, A. H., Hering, S. V., and Hammond, S. K.: Characterization of polycyclic aromatic hydrocarbons in motor vehicles fuels and exhaust emissions, Environ. Sci. Technol., 33, 3091-3099, 1999.

Masclet, P., Cachier, H., Liousse, C., and Wortham, H.: Emissions of polycyclic aromatic hydrocarbons by savannah fires, J. Atmos. Chem., 22, 41-54, 1995.

Menichini, E., Montfredi, F., and Merli, F.: The temporal variability of the profile of carcinogenic polycyclic aromatic hydrocarbons in urban: a study in a medium traffic area in Rome, Atmos. Environ., 33, 3739-3750, 1999.

Mi, H. H., Lee, W. J., Chen, S. J., Lin, T. C., Wu, T. L, and Hu, J.C.: Effect of gasoline additives on PAH emission, Chemosphere, 36(9), 2031-2041, 1998.

Miguel, A. H. and Pereira, A. A. P.: Benzo(k)fluoranthene, Benzo(ghi)perylene, and Indeno(1,2,3-c,d)pyrene: New tracers of automotive emissions in receptor modelling, Aerosol Sci. Technol., 10, 292-295, 1989.

Miguel, A. H., Kirchstetter, T. W., Harley, R. B., and Hering, R. A.: On-Road emissions of particulate polycyclic aromatic hydrocarbons and black carbon from gasoline and diesel vehicles, Environ. Sci. Technol., 32, 450-455, 1998.

Nielsen, T.: Traffic contribution of polycyclic aromatic hydrocarbons in the center of a large city, Atmos. Environ., 30, 34813490, 1996.

Nikolaou, K., Masclet, P., and Mouvier, G.: Sources and chemical reactivity of polynuclear hydrocarbons in the atmosphere a critical review, Sci. Total Environ., 32, 103-132, 1984.

Nolte, C. G., Schauer, J. J., Cass, G. R., and Simoneit, B. R. T.: Highly polar organic compounds in wood smoke and in the ambient atmosphere, Environ. Sci. Technol., 35, 1912-1919, 2001.

Oros, D. R. and Simoneit, B. R. T.: Identification and emission rates of molecular tracers in coal smoke particulate matter, Fuel, 79,
515-536, 2000.

Oros, D. R. and Simoneit, B. R. T.: Identification and emission factors of molecular tracers in organic aerosols from biomass burning Part 1, Temperate climate conifers, Appl. Geochem., 16, 1513-1544, 2001a.

Oros, D. R. and Simoneit, B. R. T.: Identification and emission factors of molecular tracers in organic aerosols from biomass burning Part 2, Deciduous trees, Appl. Geochem., 16, 1545-1565, 2001b.

Pankow, J. F. and Bidleman, T. F.: Interdependence of the slopes and intercepts from log-log correlations of measured gas-particle partitioning and vapor pressure, I. Theory and Analysis of available data, Atmos. Environ., 26A, 1071-1080, 1992.

Paturel, L., Saber, A., Combet, E., and Joumard, R.: Analysis of PAH emissions from passenger cars by high resolution Shpol'skii spectrofluorimetry, Polycyclic Aromatic Compounds, 9, 331-339, 1996.

Penner, J. E. and Novakov, T.: Carbonaceous particles in the atmosphere: A historical perspective to the fifth international conference on carbonaceous particles in the atmosphere, J. Geophys. Res., 101, 373-378, 1996.

Pistikopoulos, P., Masclet, P., and Mouvier, G.: A receptor model adapted to reactive species Polycyclic Aromatic Hydrocarbons; evaluation of source contributions in a open urban Site - I. Particle Compounds, Atmos. Environ., 24A, 1189-1197, 1990a.

Pistikopoulos, P., Wortham, H. M., Gomes, L., Masclet-Beyne, S., Bon-Nguyen, E., Masclet, P., and Mouvier, G.: Mechanisms of formation of particulate aromatic hydrocarbons in relation to the particles size distribution Effects on meso-scale transport, Atmos. Environ., 24A, 2573-2584, 1990 b.

Prévôt, A. S. H., Dommen, J., Bäumle, M., and Furger, M.: Diurnal variations of volatile organic compounds and local circulation systems in an Alpine valley, Atmos. Environ., 34, 1413-1423, 2000.

Rogge, W. F., Hidemann, L. M., Mazurek, M. A., and Cass, G. R.: Sources of fine organic aerosol 2. Noncatalyst and catalystequipped automobiles and heavy duty diesel trucks, Environ. Sci. Technol., 27, 636-651, 1993.

Rogge, W. F., Hidemann, L. M., Mazurek, M. A., and Cass, G. R.: Mathematical modeling of atmospheric fine particulateassociated primary organic compounds concentrations, J. Geophys. Res., 101, D14, 19379-19394, 1996.

Rogge, W. F., Hidemann, L. M., Mazurek, M. A., Cass, G. R., and Simoneit, B. R. T.: Sources of fine organic aerosol 9. Pine, Oak, Synthetic Log combustion in residential fireplaces, Environ. Sci. Technol., 32, 13-22, 1998.

Schauer, J. J., Rogge, W. F., Hildemann, L. M., Mazurek, M. A., and Cass, G. R.: Source apportionment of airborne particulate matter using organics compounds as tracers, Atmos. Environ., 30, 3837-3855, 1996.

Schauer, J. J. and Cass, G. R.: Source apportionment of wintertime gas-phase and particle-phase air pollutants using organic compounds as tracers, Environ. Sci. Technol., 34, 1821-1832, 2000.

Schauer, J. J., Kleeman, M. J., Cass, G. R., and Simoneit, B. R. T.: Measurement of emissions from air pollution sources, 3. C1-C29 organic compounds from fireplace combustion of wood, Environ. Sci. Technol., 35, 1716-1728, 2001.

Schauer, J. J., Kleeman, M. J., Cass, G. R., and Simoneit, B. R. T.: Measurement of emissions from air pollution sources, 5. C1-C32 
organic compounds from Gasoline-Powered Motor Vehicles, Environ. Sci. Technol., 36, 1169-1180, 2002.

Schnelle-Kreis, J., Gebefügi, I., Welzl, G., Jaensch, T., and Kettrup, A.: Occurrence of particles-associated polycyclic aromatic compounds in ambient air of the city of Munich, Atmos. Environ., 35, S71-S81, 2001.

Seinfeld, J. H. and Pandis, S.: Atmospheric Chemistry and Physics: From Air Pollution to Climate Change, Wiley Interscience, New York, 1998.

Simoneit, B. R. T.: Biomass burning - A review of organic tracers for smoke from incomplete combustion, Appl. Geochem., 17, 129-162, 2002.
Standley, L. J. and Simoneit, B. R. T.: Characterization of extractable plant wax, resin and thermally matured components in smoke particles from prescribed burns, Environ. Sci. Technol., 21, 163-169, 1987.

Tsapakis, M. and Stephanou, E. G.: Collection of gas and particle semi-volatile organic compounds: use of an oxidant denuder to minimize polycyclic aromatic hydrocarbons degradation during high-volume sampling, Atmos. Environ., 37, 4935-4944, 2003.

Venkataraman, C. and Friedlander, S. K.: Size distributions of Polycyclic aromatic hydrocarbons and elemental carbon, 2. Ambient measurements and effects of atmospheric processes, Environ. Sci. Technol., 28, 563-572, 1994. 